\title{
Preservation of Minority Languages in North America: French Immersion Programs in the Province of Alberta
}

\author{
Baltasar J. López Ruiz \\ Departamento de Lenguas Extranjeras y sus Lingüísticas, Facultad de Filología, UNED, Madrid, Spain \\ Email: baltasarlopez@fundacionsafa.es
}

Received 22 January 2015; accepted 7 April 2015; published 10 April 2015

Copyright (C) 2015 by author and Scientific Research Publishing Inc.

This work is licensed under the Creative Commons Attribution International License (CC BY). http://creativecommons.org/licenses/by/4.0/

cc) (i) Open Access

\begin{abstract}
Canada, which was officially declared a bilingual nation after the proclamation of the Official Language Act (1969), counts with a low percentage of French speaking population who hardly reaches a quarter of the total population. We must add the fact that there is a very little fraction of the population who speaks French outside the province of Quebec. Social, cultural and ethnic realities which are present within the Canadian territories enable us to observe and investigate the diversity of identities and the different linguistic assimilation processes experienced by non Anglophone citizens. Facts seem to indicate that the francophone minority groups, living in areas of the country where the most spoken language is different from their mother tongue, struggle for the preservation of their cultural heritage at the same time that keep alive their Canadian identity. The possibility of contrasting the situation of the Francophones in Western Canada with the reality of other minority groups which represent a similar percentage with respect to the total population-such as the Germans and the Ukrainian origin citizens-constitutes a valuable resource in order to predict the evolution of the demographic patterns and the use of French as a heritage language within the Canadian territories. The present work reviews the diverse political, linguistic and demographic contexts that may support our idea that using an additional languageFrench and English in the case of most Francophones in Western Canada-represents an advantage from a cognitive, social and linguistic point of view. The high degree of acceptance of the francophone schools and the popularity of the French immersion programs set up by Albertan authorities are considered within this article in order to support this hypothesis.
\end{abstract}

\section{Keywords}

Minority, Language, French Immersion, Alberta, Canada 


\section{Introduction}

Bilingualism has become a remarkable trait of Canada. The Official Languages Act (1969) was conceived to preserve the rights of both Francophone and Anglophone citizens to use their mother tongue and have the right to access to basic services in their main language. This act provides that the English-speaking and Frenchspeaking Canadians must not be discriminated against on the basis of their ethnic origin or first language on the issue concerning equal opportunities for employment. However, if we do not count the jobs in the administration in the required bilingual staff, most of the jobs taken up by Francophones in Alberta require knowledge of the English language.

The Official Languages Act (1969) establishes that there must be a significant demand for services in French language to set up the necessary measures that can assure public services in this language. Around this concept, the Act interprets that there is sufficient demand to provide public services in French in those areas of Alberta where there are at least 5000 people registered by the Canadian Census as long as the Francophone citizens represent a percentage greater than or equal to $5 \%$ of the total population in that area.

This reality shows how official status is not always linked to the preservation of a certain language and culture. British and French origin people have managed to maintain their cultural heritages to some extent.

Linguistic diversity marks important differences when we compare Canada and the United States. The Constitution of the latter does not make any reference to linguistic policies. The term minority in the United States as an element that segregates colored people from other ethnic groups has been analyzed. Some authors stated that prejudices and misconception of the ideal of multiculturalism have led on some occasions to racial tensions that jeopardize social harmony in this country [1].

On the contrary, Canada has set up linguistic programs that allow students to attend school where the languages of the different ethnic groups are taught. Educational programs carried out by Albertan authorities, especially in Edmonton and Calgary have also made a positive contribution to the preservation of the language and cultural heritage of the French descendants living in the areas administered by these school districts. Research on bilingualism and language policies has focused on education and federalism or on Francophone minorities outside Quebec. Some researchers who have reviewed the political and demographic contexts that justify the advantages of using an additional language show that bilingualism is cognitively, socially and linguistically advantageous for citizens as well as for Canadian society [2]-[4].

The work of Francophone school districts seems vital to extend the network of centers offering educational programs in French all over the province. The implementation of language immersion programs also guarantee success among the Anglophone population that progressively become interested in French culture and language and those who consider that their children can benefit from knowing the two official languages of the country. As regards the educational aspect, we can evidence that the policies implemented by the education authorities to promote the French language in the province of Alberta are beginning to show some results. Statistical data provided by Alberta Education confirm that the number of students in French-language schools has increased during the last decade. ${ }^{1}$

\section{The Francophone Minority Groups within Western Canada Cultural Mosaic}

The last census available at the time of our investigation shows that the French speakers in western provinces of Canada such as Alberta represent a minority group of population, with a percentage to the total population of $1.88 \%$. Only $0.59 \%$ of the population of Alberta uses French as the common language at home, which shows that the Francophone use English at work and in their daily lives [5].

When we compare to other minority groups where one of the two official languages of Canada is spoken, Albertan Francophones show a considerable ageing population. Despite these negative parameters, the French speaking population in Alberta has increased 2.1 per cent since 1996 as stated in the Canadian Census. The reasons that may justify this rise in the Francophone population seem to be the increase in the interprovincial migration together with the international arrival of French speaking citizens.

The search for elements that best describe the current situation of the descendants of the first French explorers becomes useful when trying to verify if there still exist noticeable bonds that link all the Francophone communities dispersed all over the western regions of Canada. As a matter of fact, in western regions like Alberta, most

\footnotetext{
${ }^{1}$ Alberta Education is the name given to the Ministry of Education of the Government of the Alberta. It is responsible for the development of curriculum, teacher certification and regulates education policies.
} 
of the francophone communities are scattered in the province, mainly in villages where Francophones make up less than five percent of the total. Only in some localities of the Rivière-la Paix region we can find locations such as Donnelly, Falher, Girouxville, Smoky River, where Francophones are today a majority [6].

Western provinces of Canada attract many citizens as a consequence of the economic prosperity of the region, especially in the province of Alberta. Migration flows arriving in the city of Edmonton over the last two decades have been attracted by jobs in the oil sector. The discovery of large tracts of oil sands in Alberta has made of Edmonton region one of the areas with the highest income per capita in the country. A significant number of workers who move to Alberta from other provinces in Canada to work in this industry are citizens of Quebec.

Despite that fact that most of the francophone population that recently settled in Edmonton and other areas of the province of Alberta are citizens of the province of Quebec, Canadian Census data from 2001 and 2006 make us envision an increase in the Francophone immigrant population coming from other countries, mainly in Africa, and can be included in the group of people who have been listed as Francophone minorities despite not sharing cultural roots with the rest of the French-speaking population. The French-speaking immigrant population that has been established in Alberta, mainly from African countries, has not necessarily integrated into existing Francophone communities. In fact, many of them seem to be assimilated by the English-speaking community that constitutes the largest group [7].

Data show that the proportion of Francophone immigrants established in Alberta increased by six percent through the two last decades. In fact, one out of ten Francophones in Alberta has been born outside Canada (Statistics Canada, 2012). The number of African origin Francophones has also increased in schools located in urban centres: Notre Dame, Père-Lacombe, Maurice-Lavallée, Gabrielle-Roy, Desrochers and Saint Christophe [8].

The Francophone population has concentrated within Northern rural regions of the province. Several villages-Fahler, Donnelly, Girouxville and Smoky River are populated by a French speaking majority. The geographic area that surrounds this region, known as Rivière-la-Paix, is mainly occupied by English speaking population. With the purpose of adapting to new social and economic situation, the descendants of the Francophone inhabitants in these regions are deciding to abandon these villages and are currently migrating to bigger cities such as Edmonton, Calgary or Vancouver.

Many families currently opt for spreading over the territory so that the Provincial Government authorizes them to create new Francophone schools. ${ }^{2}$ Most descendants of third and fourth generation that decided to remain in these areas and devote themselves to agriculture live nowadays in an English speaking environment. A high percentage of these citizens are bilingual although they seem to be determined to preserve their cultural and linguistic heritage.

\section{The Francophones and Their Struggle for the Preservation of the Francophone Heritage Culture in Alberta}

The vitality of Francophone communities has been an object of debate. The use of the concepts such as "assimilation" and "vitality" constitute topics of public debate in Canada. O'Keefe (2001) explored these concepts as supports his theory with statistical evidences regarding the vitality of Francophone community groups in provinces of Canada outside Quebec [9]. Thériault (1999), Langlois (2004) and later Langlois and Gilbert (2006) together with other authors such as Dallaire (2008) have made substantial contributions to the interpretation of plurality, especially on those aspects regarding francophone minority groups. These analyses of the Francophone communities in this country provide us with arguments that confirm that the vitality of the francophone minorities in Canada has not been fully understood [10]-[13].

O'Keefe (2001) identifies the main factors that influence the vitality of a minority language. As stated by this author, the fact that a language is official or the circumstances that do not permit the accomplishment of certain activities in a certain language is described as a symbolic factor. This author also concludes that demographic and institutional factors may determine the vitality of a language. Demographic factors make reference to the number of speakers, the proportion with respect to total population and fertility rate. Institutional factors are related to the role of governmental and other institutions related to the control and management of the language services offered to the community.

Education is cited by O'Keefe (2001) as another relevant factor that must be taken into account when dis-

\footnotetext{
${ }^{2}$ As stated by the Section 23 of the Charter of Rights and Freedoms, citizens are granted the right to be taught in their mother tongue if they represent a significant percentage of the total population.
} 
cussing the vitality of a minority language. The maintenance of a language would be associated to the extent and the quality of the education services available in a certain language. Other factors mentioned in his publication are the prestige of the language at international level, identity (sense of community) and the social utility of the language.

A historical overview of the colonization process initiated by French and British citizens in North America starting in the seventeenth century can be considered in order to analyze the processes of integration and cultural assimilation of the French speaking population within the rest of ethnic groups that have evolved towards what has been called Canadian Mosaic.

Successive adaptations of francophone settlers led to important changes in their habits and circumstances, mainly after the arrival of newcomers from Eastern Europe. In Alberta, the most significant event as regards the immigration process and the arrival of European settlers turns to be the settlement of the Ukrainians throughout the first half of the twentieth century [14].

After the arrival of British settlers and other citizens who settled in the western areas of Canada in search for gold in the nineteenth century, Canadian society turned into one of the most important areas for the reception of immigrants worldwide. This position would be held up to the end of the Second World War [15].

Francophones have been continuously surrounded by English speaking communities in most Canadian territories. This fact evidences the need for striving in order to preserve French language and culture as a symbol of survival despite the adversities associated to the omnipresence of English language and Anglo Saxon cultural influences. In such a linguistic and cultural diverse society, new groups of population have progressively fitted in order to knit this complex mosaic, striving for the preservation of their own traits and identity [16]. This statement would lead us to assume that the construction of the Canadian society has consequently derived into a situation in which French heritage and language has been continuously relegated to a secondary and less relevant position.

The simultaneous flux of British, Irish and French origin groups of population into Canada have contributed to social and political conflicts still pending to be solved. The thorough analysis of these tensions permit to look into the difficult relations established among British descendants and French settlers in order to reach objective conclusions regarding relevant aspects such as acculturation processes and language assimilation.

Current policies on multiculturalism and bilingualism have opened Canadian borders to Francophone citizens of diverse origins, forcing society to recognize and reconsider the actual reality and diversity of the francophone communities within Canada. In a pluralistic and multicultural society it is important to make people understand there is not just the "majority" on one side and visible minorities on the other side. In order to put in perspective the multicultural nature of Canada, the relationship among minorities and these "new" Canadian citizens needs to be analyzed.

\section{Immigration and the "New" Francophone Identities}

The Multiculturalism Act in 1988 officially recognized Canada as a multicultural nation [17]. The idea of pluralistic and multicultural society officially took place when the Bill was introduced in the House of Commons by the Prime Minister Pierre Trudeau in 1972. In major Canadian cities, French origin population is no longer representative and Chinese and Indo-Canadian groups are becoming dominant ethnic groups. Ethnic perception of French language represents an invisible barrier within Francophone communities in Alberta. Language marks the exclusive line against Anglophone assimilation policies that historically have menaced Franco-Albertan identity

If we focus on the province of Alberta, data related to population census show that in 2006, this province registered 9210 newcomers from other Canadian provinces whose mother tongue was French. The four Canadian provinces that contributed with the highest number of francophone newcomers were Quebec (3810), followed by Ontario (1940), New-Brunswick (1085) and British Columbia (1020). Moreover, the Canadian census reports a considerable number of immigrants of African origin who arrived in Alberta between years 2001 and 2006 . In fact, data retrieved from Statistics Canada referred to this time interval show that 12530 immigrants reported an African country as their country of origin. Among the countries that contributed with the highest number of francophone immigrants, the census included Congo (320), Rwanda (175), Algeria (155) and Morocco (105) [18].

Some investigations focused on the Francophone minorities shed light on sociological aspects such as the 
presence of minorities within a minority. Studies conducted by the University of Calgary in the last decade have focused on minority sectors of francophone black population that coexist within other Francophones from different backgrounds [19].

Some cities in Alberta receive each year considerable contingents of French speaking immigrants. This fact permits institutions to implement programs and measures conceived for a better integration of these minority groups. In smaller villages, immigrants find more hostile conditions that endangered the consolidation of their social, cultural and linguistic integration. Social attitudes shown by the members of Francophone communities regarding racial differences between white French origin citizens and West African French speaking communities do not seem to facilitate the integration of Francophone immigrants in Alberta French is often understood as an occidental language, spoken by citizens of French origin. This ethnic vision of the language may lead into an exclusive Francophone identity [20] [21].

Madibbo (2010) expresses how difficult the situation experienced by black immigrants to integrate within francophone communities previously settled in some regions of Canada outside Quebec is. The arrival of immigrants from Africa to provinces such as Alberta has consequently derived into a considerable increase in the number of Francophones living in this province. However, testimonies of these African citizens settled in Alberta show that most of them tend to integrate within Anglophone communities. Documentaries and press articles reflect on some occasions that they do not always identify with the culture and traditions of French settlers descendants living in Western Canada. Francophone immigrants in Alberta seem to develop multiple forms of belonging to many social groups. This phenomenon is manifested by means of a collective sense of adherence both to their ethnic community and to the francophone community and the Canadian society in general [22].

The cultural and racial diversity of the Francophone groups of population in Alberta has even contributed to a controversial debate within representative Albertan associations. This issue has been seen by many as a sign of division within the Francophones in Alberta and has been an object of debate in studies focused on the inclusion of francophone immigrants coming from Africa within the host francophone communities in Alberta [23].

The debate about the need for reflection on inclusive identity within Francophone minorities has been suggested. It would be necessary to project Francophone identity including other aspects different from linguistic (reference to values, beliefs and traditions). The objective of this new vision would be to re-define the Francophone identity, adapted to their plurality and inner diversity [24].

\section{School Policies in Alberta: French Immersion and Bilingual Programs}

Our research on the francophone communities appears as a complicated issue due to the multiplicity of "francophone" identities depicted in previous literature. The concept of "Francophone" within the Canadian Prairies includes multiple elements associated to a great diversity of citizens that contribute to some extent to the "Francophonie" in this region of the country. Aside from the French descendants, the Eastern Canadian citizens from Quebec and the African origin immigrants, the "Francophone" identity should also comprise those groups of population who are determined to approach and establish significant links with the Francophone heritage culture and language. Ethnographic research focused on the identity of French immersion students in Canada include studies that show that these students develop their own bilingual identity, which is not recognized in the Canadian society [25].

In 1963, the Federal Government created the Commission for Bilingualism and Biculturalism in order to elaborate a report on the situation of the country regarding these two aspects. The final report of the Commission encouraged the Government to allow parents to decide the official language preferred for their children's instruction [26]. In 1968, the Alberta School Act was modified and gave permission to receive instruction in French language in K-12 programs during a limited time that could not exceed fifty per cent of the total time of instruction. ${ }^{3}$ Nevertheless, Alberta's Government did not estimate necessary the separation of Anglophone and Francophone population to receive instruction in French language.

It was considered that the admission to educational programs in French language should not depend on the mother tongue of the students. According to Alberta Government, a considerable number of school districts were able to preserve their French programs thanks to the elevated number of Anglophone students that enrolled in them. The decision of the provincial government of not giving the opportunity to Francophones to receive

\footnotetext{
${ }^{3}$ Alberta educational system offers K-12 programmes that include Elementary School (Grades 1-6), Junior High School (Grades 7-9) and High School (Grades 10-12).
} 
French instruction separately was, however, contradicting the recommendations published by the Commission for Bilingualism [27].

The Official Languages Act (1969) guarantees the right to access to federal and provincial public services using either language, French or English. When the Official Languages Act was passed in year 1969, only nine per cent of the jobs created by the Federal Government were occupied by French speaking citizens. The number of positions offered by the Government has continuously increased from 14 per cent in 1978 up to $25 \%$ in 2004. In 2007, Francophones occupied $26.9 \%$ of the total amount of positions in institutions subject to the Official Languages Act [28].

The Official Languages Act (1969) might however have different interpretations. The Law regulates the access to public services in one of the official languages as long as there is a significant demand. The term significant has been object of controversy since it is interpreted as the existence of a nucleus of population with more than 5000 habitants where more than 5 per cent of the citizens belong either to a Francophone or Anglophone minority, depending on the part of the country we make reference to.

The Canadian Federal Government approved the Canadian Charter of Rights and Freedoms in 1982. Section 23 of this charter granted students belonging to French language minorities the right to receive education in their mother tongue. Parents of francophone students were also given access to the management and control of the educational institutions where their children were schooled.

The establishment of entirely francophone schools does not seem to have been an easy task in Alberta. Francophone communities have been forced to protest against the provincial government to have their rights recognized. The claims for francophone parents' rights in order to participate in the decisions of the provincial government in questions concerning the education of their children started in 1986. At that time, the Education Department of the ACFA created the Fédération des Parents Francophones de l'Alberta, FPFA (Alberta Francophone Parents Association). The objective of this association was to concentrate the efforts of all the different committees that francophone parents had established all over the province.

The first francophone school that was created in Alberta started to operate in Edmonton. The primary school École Maurice-Lavallée was opened in 1984 under Edmonton Separate School Board jurisdiction. After the Supreme Court resolution with respect to the Mahé case, a series of measures were taken to make sure that school boards were complying with the regulations of the $23^{\text {rd }}$ Section of the Canadian Charter of Rights and Freedoms [29].

In Alberta, the proportion of students that attend francophone schools has steadily increased throughout the last decade. In the school year 2001/02, only $0.55 \%$ of the students in Alberta went to a francophone school. Ten years later, in 2012, this percentage had gone up to $1.01 \%$. In addition to the existence of Francophone and French Immersion schools, Albertan authorities have set up different bilingual education programs. In year 2014, Alberta offers both French immersion and Language bilingual programs in several Heritage Languages. ${ }^{4}$

In the past, students in Bilingual Programs were typically third and fourth generation immigrants to Canada with little or no knowledge of the language. Nowadays, the goals of Bilingual Programs are to provide students with the opportunity to learn and communicate in two languages at the same that they can develop, understand and appreciate other cultures, languages and religions. Albertan School authorities seem to encourage linguistic diversity in the students of the province. Alberta Education provides opportunities for students to pursue a language that is not their first language.

The instructional time spent in the specific international language varies from province to province. The Common Curriculum Framework for Bilingual Programming in International Languages was developed through the cooperation of the provinces of Alberta, Manitoba and Saskatchewan. The bilingualism promoted in these programs has been termed as "one-way additive bilingualism" as it is assumed that at their home they speak English with their families. Research conducted in Canada assures that children's level of English is not in danger when they acquire a second language [30].

Despite all these advantages mentioned, it is argued that many school administrators have to face new problems in programming, managing and supervising instructors and documents written in languages that they do not understand.

\footnotetext{
${ }^{4}$ According to Canadian Education Association, these are the languages of origin or first language of one's parents or one's ancestors. The term "heritage language" usually refers to all languages other than the aboriginal languages of Native peoples and the official Canadian languages (English and French).
} 


\section{Rapprochement between Anglophones and Francophones in Alberta: Is Education a Possible Solution?}

The Francophone identity in the central provinces of Canada is not as well defined as it could be either in Quebec or in the Maritimes provinces. This is due to the fact that most French speaking citizens in the Prairies are bilingual and also because of the vast distance that separates them from the rest of francophone communities in the country.

Although federal and provincial policies try to guarantee the access to education and the labor market, giving equal opportunities to people of all ethnic groups in Canada, it is not always clear under which conditions Francophone citizens who come from other countries are granted the access to public services. The Francophones who currently arrive in the Western Canada are mostly coming from the province of Quebec and some African countries where French is still used officially or as a vehicular language.

Western Canadian provinces have received a large number of Francophones from a wide variety of ethnic, cultural and racial backgrounds migrating from Eastern Canada. The start of this movement was marked in the late 1990s by the arrival of families of African origins, first from Congo and Rwanda and later from Somalia and Morocco. Although these families constituted only a minority of the newly-arrived Francophone population in Alberta, their arrival has been particularly striking for certain sectors of the francophone population.

The absence of educational programs specifically designed for newcomers together with the lack of support from ancient Francophone communities seem to be the cause that justifies that the French-speaking immigrant population that decided to settle in Alberta in recent decades, mainly those from African countries, do not necessarily integrate into existing Francophone communities. Consequently, many of these francophone newcomers are assimilated by the English-speaking community that constitutes the largest group.

Education appears as one of the most relevant elements that contribute to the vitality of the language and traditions of the different ethnic groups which are present in Alberta. According to the data offered by the main school districts in the province, the evolution of the second language immersion programs and the bilingual programs implemented by Albertan government have contributed to an increase in the number of citizens that opt for an educational program in which they can preserve their mother tongue.

The efforts made by the francophone school districts have been vital to extend the network of schools offering educational programs in French all over the province. The implementation of language immersion programs is specially succeeding among the Anglophone citizens who become interested in French culture and language and also among English speaking parents who firmly believe that their children can benefit from knowing the two official languages of the country. The case of Alberta is an example of change in the mentality of the Anglophone parents, since many of them decide to send their kids to French immersion programs so that the latter have better options to become bilingual and find a job in the future.

A brief analysis of the role played by public and private institutions in promoting the French language and culture permits us to conclude that the efforts made by the government's institutions to provide public services to citizens in French are still insufficient in order to improve the living conditions for many Francophones in the Canadian Prairies provinces. It seems accurate to say that there are still many services to which citizens have restricted access in Alberta if they do not know English. The legislative framework sets out vague requirements for public services to be provided in both official languages.

When examining the factors that may determine the vitality of minority languages in Canada, we must notice that the preservation of French language in Canada is somehow bound to the introduction of new technologies related to communication, which definitely increase the possibilities for young English speakers to approach French language and culture.

\section{General Discussion and Conclusion}

Francophones outside Quebec live in a wide variety of environments. Some communities such as Saint-Boniface, close to Winnipeg (Manitoba) or Grande Prairie (Alberta) stand as a representative example for a historical community. However, other Francophones live in contexts where they have no geographic or historical reference, but they have infrastructures such as schools, community centers, radio stations and newspapers that offer the possibility of keeping the French language alive.

The concept of community has been the subject of debate and has been redefined. The spatial conception of community must be challenged in order to look into other interactions and personal networks that are not related 
to a geographical location.

The use of English in the province of Quebec, mainly francophone, has been linked to the presence of a larger North American society (overwhelming English) to explain the vitality of the English language in this province. In the same way, the points of view shown by the different studies focused on Francophones outside Quebec shown in this article evidence the necessity of reexamining the role of bilingual speakers in the preservation of the language.

The conclusion we may draw from our study on the francophone communities is that the promotion of bilingualism across Canada would be an effective measure to preserve French in those territories where it constitutes a minority language. The two different models of bilingualism—additive and subtractive-proposed by Landry and Bourhis (1997) appear as a consequence of the personal aptitudes and the individual's linguistic competences [27]. We should assume that a positive attitude towards the other official language different from the mother tongue and the implementation of language programs in the two official languages across Canada would derive into an additive bilingualism, without the loss of the citizen's native language.

We may consider that the implementation of other types of policies in order to guarantee the continuity of bilingual programs at postsecondary level would be an effective way of enlarging the "francophone space". By doing so, students would be capable of mastering the language and feel able to use it with native speakers of their ethnic origin communities. The low rate of students who decide to enroll in a francophone university in the western provinces of Canada leads us to think that there is a lack of continuity between secondary and university studies within the French language programs.

It may be assumed that an increase in the undergraduate and postgraduate programs offered by Francophone universities would enhance the opportunities of francophone citizens to take up a professional career within the federal services where the knowledge of the two official languages is required. The knowledge of French language on the part of university students would also facilitate their incorporation to the labor market in those provinces of Canada where the French language has a relevant role-Quebec or New Brunskwick, for instance.

Our first interpretation of the historical facts related to the relations between British and French descendents in Canada would let us depict both groups of population in a permanent situation of antagonism and continuously opposed. In fact, a literature review of the visions presented by different authors (Coleman, 1993; Logan, 1997; Wade \& Falardeau, 1960) seems to emphasize the differences existing between both ethnic groups. From a historical point of view, both French and British settlers exerted an enormous influence on the territorial distribution of the population as well as on the aboriginal population present in Canadian territories before the arrival of the European settlers [31]-[33]. By contrast, Canadian society is frequently seen as an example of respect and social integration of the multiple ethnicities and cultures that co-exist and share common values such as tolerance and mutual understanding.

These contradictory positions could lead us to two different interpretations.

On one side, we may think of the French-speaking minority as a sector of the Canadian population apparently integrated into the global society, commonly denominated "mosaic". On the contrary, we might interpret facts in terms of the lack of an identified symbol-either political or religious - that jeopardizes the heritage culture and traditions of all the minority groups present in this country and which results in assimilation. The world financial crisis has resulted in the loss of many of the French-speaking positions and the job market for the Francophones in Western regions of Canada has become even tighter when compared to previous generation [34]. Some of the francophone institutions which receive public funds are suffering dramatic adjustments in their budgets, which is menacing the continuity of their services to the francophone community.

The creation of new bilingual positions by the Canadian government does not seem to meet the expectations of the new generations of French speaking citizens who wish to incorporate into the francophone labor market. The new generations of Francophones who are joining the workforce are also witnessing tensions derived from the incorporation of Francophone immigrants with full mastery of the French language.

The province of Alberta can be considered a positive model in the field of education. Financial investment on educational programs in this province has considerably increased the opportunities of the Francophones to pursue their studies in French language. On grounds of the success of the second language immersion programs and the bilingual education system implemented by Albertan authorities, it must be considered that these sorts of measures would additionally preserve the vitality of the Anglophone communities in eastern regions of the country within the province of Quebec and New Brunswick.

The conclusions presented in this article lead us to the necessity of creating a common space which makes 
possible the rapprochement between Anglophones and Francophones across the country. Future generations of Canadian francophone citizens are to face the challenge of finding their right place in an increasing diversity of languages and cultures. A more demanding attitude of the Francophones and a more positive vision of the francophone communities on the part of the Anglophone majority could be the first pillars in the construction of the common space here referred, where both official languages find the optimal conditions to cohabitate and both cultures be effectively enriched by the mutual interaction of their peoples.

\section{References}

[1] Paterson, D., Willoughby, D. and Willoughby, S. (2001) Civil Rights in the USA 1863-1980. Heinemann Educational Publishers, Oxford.

[2] Cardinal and Lapointe, J. (1990) Immigration in Canada: A Portrait of the Foreign Population, 2006. Canadian Ethnic Studies, 22, 47-66.

[3] Duff, P. (2007) Second Language Socialization as Sociocultural Theory: Insights and Issues. Language Teaching, 40, 309-319.

[4] Hayday, M. (2005) Bilingual Today, United Tomorrow. Official Languages in Education and Canadian Federalism. McGill-Queen's University Press, Montreal.

[5] Statistics Canada (2012) Census of Canada 2011. http://www.12statcan.gc.ca/census-recensement/2011/as-sa/98-314-x2011003_2-eng.cfm

[6] Boileau, G. (2003) Les Canadiens français de Rivière-la-Paix. Histoire de Quebec, 8, 19-26.

[7] Madibbo, A. (2012) L’immigration francophone noire et le multiculturalism. In: Ewin, G. and Coates, C., Eds., Introduction aux Études Canadiennes: Histoires, identités, cultures, University of Ottawa Press, Ottawa, 121-133.

[8] Alberta Education (2014) Statistics. Education Facts, Rates and Demographic Information. http://education.alberta.ca/department/stats.aspx

[9] O’Keefe, M. (2001) Francophone Minorities: Assimilation and Community Vitality. New Canadian Perspectives, 45-71.

[10] Thériault, J.Y. (1999) Francophonies minoritaires au Canada: L’état des lieux. Editions d’Acadie.

[11] Langlois, S. (2004) Aspects de la nouvelle francophonie canadienne. Presses de l’Université Laval, Québec.

[12] Langlois, A. and Gilbert, A. (2006) Typologie et vitalité des communautés francophones minoritaires au Canada. The Canadian Geographer/Le Géographe canadien, 50, 432-449. http://dx.doi.org/10.1111/j.1541-0064.2006.00156.x

[13] Dallaire, C. (2008) La langue française en Amérique: Dynamiques spatiales et identitaires. Francophonies d'Amérique, No. 26, 357-381. http://dx.doi.org/10.7202/037989ar

[14] Bodan, S. and Kordan, M. (2001) Canada and the Ukrainian Question, 1939-1945: A Study in Statecraft. Mc GillQueen's University Press, Quebec.

[15] Douglas, R., Jones, R. and Smith, D. (2000) Origins: Canadian History to Confederation. Fourth Edition, Harcourt Canada Ltd., Toronto.

[16] Axelson, J. (1993) Counseling and Development in a Multicultural Society. 2nd Edition, Thomson Brooks/Cole Publishing Co, Belmont, CA, 76.

[17] Citizenship and Immigration Canada (2005) Annual Report to Parliament, 2005. http://www.cic.c.ca/English/resources/publications/annualreport2005

[18] Statistics Canada (2007) Census of Canada, 2006. http://www.12statcan.gc.ca/census-recensement/2006/rt-td/index-eng.cfm

[19] Madibbo, A. (2006) Minority within a Minority: Black Francophone Immigrants and the Dynamics of Power and Resistance. Taylor \& Francis Group, LLC, New York.

[20] Gallant, N. (2008) From Openness to Inclusion: Immigration and Identity in Francophone Minority Communities. In: Belkhodja, C., Ed., Canadian Issues, Spring, Berlin, 339-342.

[21] Gueye, M. (2012) L’évolution du développeent durable: La valeur ajoutée francophone. Bulletin Economia Humana, 10.

[22] Maddibo, A. (2010) The Racial and Ethnic Identity of African Francophone Immigrants. Current Research Compendium on Francophone Immigration in Canada. The Quebec Metropollis Centre, Montreal, 87-94.

[23] Mulatris, P. (2009) L’intégration des immigrants francophones dans l’Ouest du Canada: Actes du colloque. Institut pour le patrimoine de la francophonie de l’Ouest canadien, Edmonton. 
[24] Denis, A. (2008) Review Essay: Intersectional Analysis: A Contribution of Feminism to Sociology. International Sociology, 23, 677-694. http://dx.doi.org/10.1177/0268580908094468

[25] Roy, S. (2010) Not Truly, Not Entirely...Pas comme les Francophones. Canadian Journal of Education, 33, $541-563$.

[26] Hoffmann, D. and Ward, N. (1970) Bilingualism and Biculturalism in the Canadian House of Commons. Queen's Printer, Ottawa, 27.

[27] Bourhis, R. and Landry, R. (1997) Linguistic Landscape and Ethnolinguistic Vitality-An Empirical Study. Journal of Language and Social Psychology, 16, 23-49. http://dx.doi.org/10.1177/0261927X970161002

[28] Canada Government (1969) Canada Rapport de la Comision Royale d’Enquête sur le Bilinguisme et le Biculturalisme. Imprimeur de la Reine, Ottawa, 374.

[29] Mahe v Alberta (1990) 1 S.C.R. 342. http://scc.lexum.montreal.ca/en/vn/1990/volume1.html

[30] Cummins, J. (1998) Immersion Education for the Millennium: What Have We Learned from 30 Years of Research on Second Language Immersion? Proceedings of the Second Katoh Gakuen International Symposium on Immersion and Bilingual Education, Katoh Gakuen, 34-47.

[31] Coleman, M. (1993) American Indian Children at School. University Press of Mississippi, Jackson.

[32] Logan, J. (1997) North American Exploration. University of Nebraska Press, Lincoln.

[33] Wade, M. and Falardeau, J. (1960) Canadian Dualism: Studies of French-English Relations. University of Toronto Press, Toronto.

[34] Dalley, P. (2008) Immigration and Diversity in Francophone Minority Communities. In: Belkhodja, C., Ed., Canadian Issues, Spring, Berlin, 50-59. 